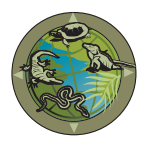

\title{
New Localities for Indian Three-banded Skinks, Eutropis trivittata (Hardwicke \& Gray 1827) (Squamata: Mabuyidae), in Central India
}

\author{
Khan Ashaharraza ${ }^{1}$ and Mandeep Kaur $^{2}$
}

${ }^{1}$ Research Administrator, Indian Herpetological Society, Pune - 411009, Maharashtra, India (ashaharrazakhan@gmail.com) ${ }^{2}$ Guru Gobind Singh Indraprastha University, New Delhi - 110078, India (scorpiomandeep_88@yahoo.com)

$\mathrm{T}_{1}^{\mathrm{h}}$ he Indian Three-banded Skink (Eutropis trivittata; Fig. 1) is endemic to southern Asia (Smith 1935; Tikadar and Sharma 1992). The species was described by Hardwicke and Gray (1827) based on specimens collected from Dum Dum $\left(22^{\circ} 37^{\prime} 12^{\prime \prime} \mathrm{N}, 88^{\circ} 25^{\prime} 12^{\prime \prime} \mathrm{E}\right)$, West Bengal, India. Recently, it has been reported from Araku, Vishakhapatnam District, Andhra Pradesh, India (Seetharamaraju et al. 2011), and Chikane (2011) commented on its distribution on the Kaas Plateau in the Satara District, Maharashtra.

While conducting extensive fieldwork on skinks in the Vidarbha Region of Maharashtra State during three seasonal years (2013-2016), we found nine E. trivittata in natural habitat. Live individuals were caught in the wild and examined for morphometric and morphological data, photographed, and released immediately. To confirm identification, we referenced material from the collection of the Bombay Natural History Society (BNHS), Mumbai, collected from Ratnagiri (BNHS 1098) and Selam (BNHS 1451). We compiled data and constructed the map in Arc GIS Version 10.2.1.

During the present study, we recorded four live individuals from Uttamsara, Pohra-Malkhed Reserve Forest, Amravati District $\left(20^{\circ} 55^{\prime} 22^{\prime \prime} \mathrm{N} 77^{\circ} 46^{\prime} 1^{\prime \prime} \mathrm{E}\right)$, including one from Vairat

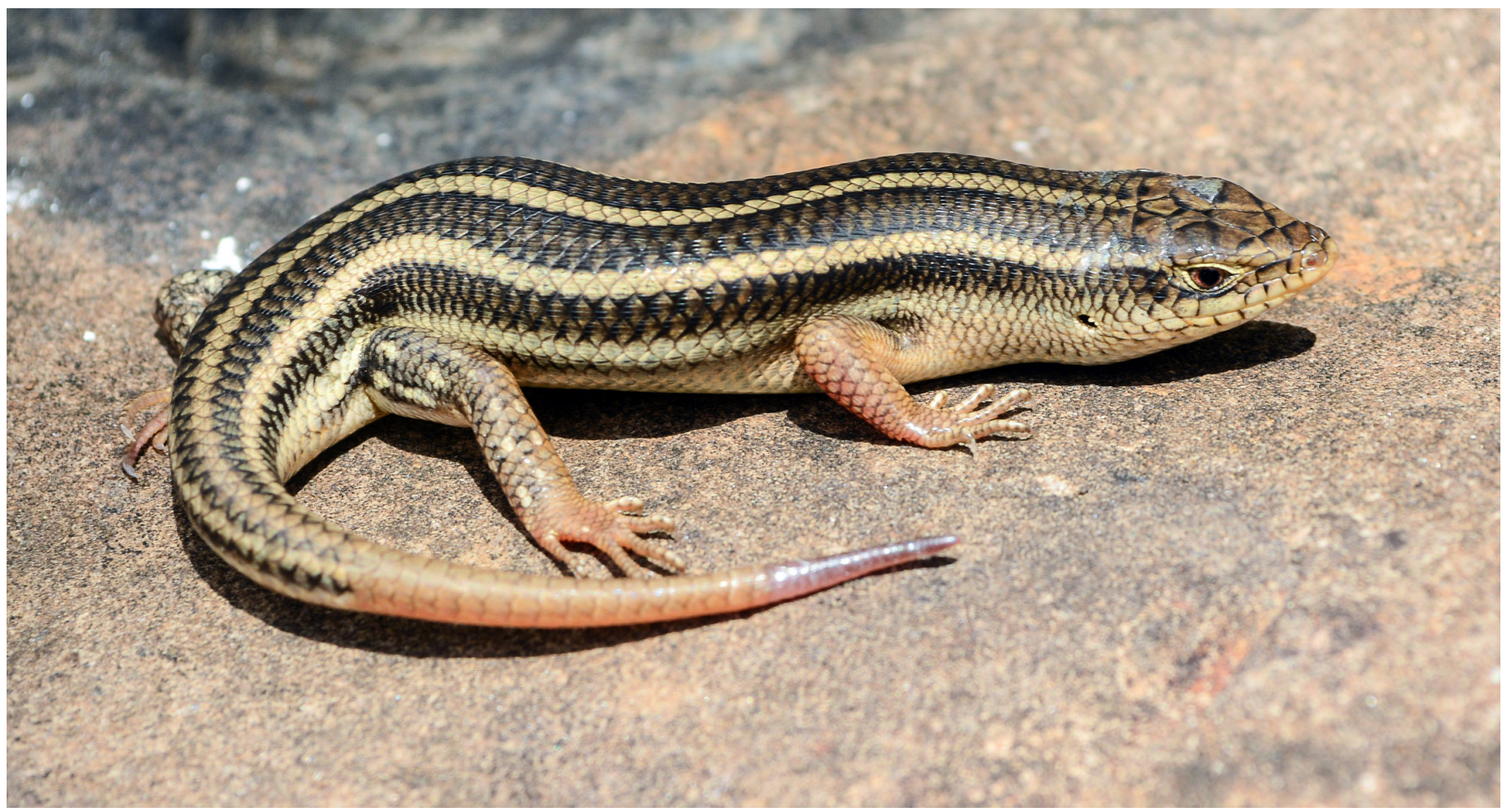

Fig. 1. An adult Indian Three-banded Skink (Eutropis trivittata) from Amravati, Maharashtra. Photograph by Khan Ashaharraza. 
$\left(21^{\circ} 23^{\prime} 2^{\prime \prime} \mathrm{N} 77^{\circ} 15^{\prime} 11^{\prime \prime} \mathrm{E}\right)$ at $-1,150 \mathrm{~m}$ asl in the Melghat Tiger Reserve. Another individual was taken in Khamgaon, Buldhana District (2042'30”N, 76³3'58'E). We sighted two individuals in the Tipeshwar Wildlife Sanctuary, Yavatmal District $\left(19^{\circ} 53^{\prime} 49^{\prime \prime} \mathrm{N}, 78^{\circ} 27^{\prime} 37^{\prime \prime} \mathrm{E}\right)$, found a roadkill in Pauni, Bhandara District $\left(20^{\circ} 47^{\prime} 30^{\prime \prime} \mathrm{N}, 79^{\circ} 38^{\prime} 0^{\prime \prime} \mathrm{E}\right)$, and acquired a photographic record from the TadobaAndhari Tiger Reserve, Chandrapur District $\left(20^{\circ} 12^{\prime} 17.5^{\prime \prime} \mathrm{N}\right.$, $\left.79^{\circ} 23^{\prime} 53.5^{\prime \prime} \mathrm{E}\right)$.
Eutropis trivittata was known previously from localities in western Maharashtra, West Bengal, Odisha, and Andhra Pradesh (Smith 1935; Tikadar and Sharma 1992; Seetharamaraju et al. 2011). Champian and Seth (2005) indicated that the forests throughout those areas range from tropical semi-evergreen forest to tropical moist deciduous forest. However, the localities documented in the present study are located on the northeastern belt of the Deccan Plateau (Gajbhiye and Mandal 2000), where the forest type is south-

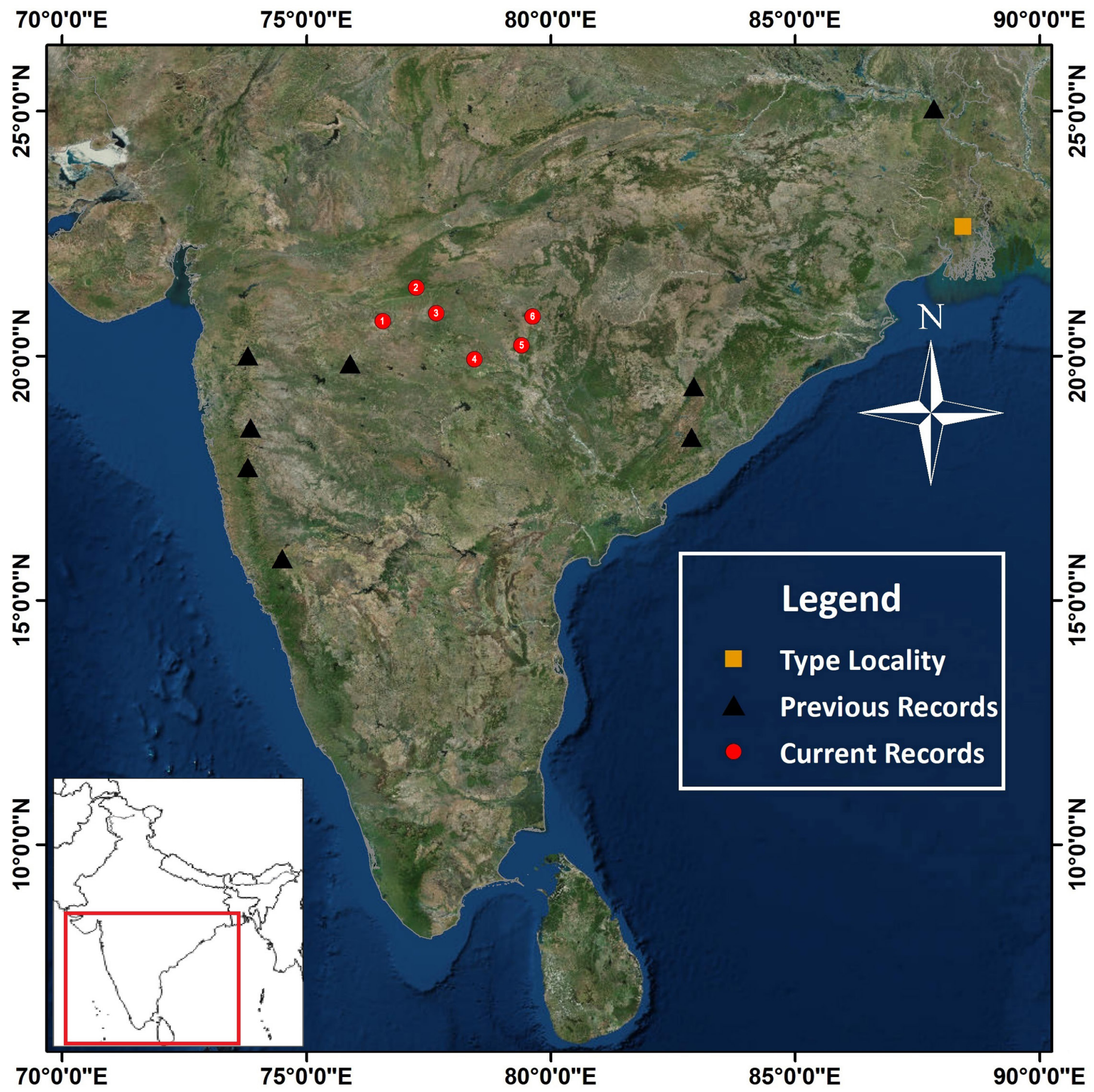

Fig. 2. Map of peninsular India showing locality records for the Indian Three-banded Skink (Eutropis trivittata). New records reported herein are: (1) Khamgaon, (2) Vairat, (3) Amravati, (4) Tipeshwar, (5) Chandrapur, and (6) Pauni. 
ern dry mixed deciduous forest (Champian and Seth 2005). The presence of the species in these areas suggests that $E$. trivittata can occur in habitats that include variable elements of arid to semiarid ecosystems.

Floral diversity in the areas inhabited by skinks included: Gum Arabic Tree (Vachellia nilotica), Teak (Tectona grandis), Flame of the Forest (Butea monosperma), Arjun Tree (Terminalia arjuna), and invasive Lantana (Lantana camara). Sympatric skinks included Golden Skinks (Eutropis carinata), Bronze Skinks (E. macularia), Lined Writhing Skinks (Lygosoma lineata), and Dotted Writhing Skinks (L. punctata). Other reptiles observed during surveys were Graceful Leaf-toed Geckos (Hemidactylus gracilis), Spinyheaded Fan-throated Lizards (Sitana spinaecephalus), Indian Smooth Snakes (Coronella brachyura), and Stout Sandsnakes (Psammophis longifrons).

Converting forests to agriculture and pastures poses a major threat to this species. Also, mortality on roads could have a deleterious effect on local populations.

The herpetofauna of the Vidarbha Region in central India is poorly documented. Our report helps to understand the distribution of E. trivittata in Maharashtra State. Previously documented from Nasik, Pune, Satara, and Jalna (Smith 1935; Chopra 1964; Baby et al. 1976; Daniels 2002; Venugopal 2010), our study confirmed the species' existence in the Vidarbha Region and fills the gap in the geographical distribution between the type locality in West Bengal and western Maharashtra (Fig. 2).

\section{Acknowledgements}

KA thanks Aniruddha D. Roy (Indian Institute of Science, Banglore) for his consistent support in KA's study of skinks. MK thanks Manish Joshi. We also thank Varad Giri (National Center for Biological Science, Banglore) for comments on an earlier version of this manuscript. Rahul Khot (Curator,
Bombay Natural History Society, Mumbai) allowed us to study materials in the collection of the BNHS, and Sushil Chikane provided literature. The Principal Chief Conservator of Forests and the Forest Department of Maharashtra granted permission to conduct surveys. Kiran Bawaskar (National Environmental Engineering Research Institute, Nagpur) encouraged biodiversity assessment studies in Khamgaon and acknowledges Viju Khandagare for collecting specimens in Khamgaon, Buldhana District. Manoj Bind provided equipment for photographic documentation. Sandeep Belkhede, Ajay Verma, Madhao Vaidya, Dinesh Khate, Shubham Sayanke, and Mukesh Malwe assisted us during field surveys.

\section{Literature Cited}

Baby, T.G., S.C. Goel, and S. Raghupathi Rami Reddy. 1976. A comparative study of arginase activity in lizards. Physiological Zoology 49: 286-291.

Champion, H.G. and S.K. Seth. 2005. A Revised Survey of Forest Types of India. Government Press of India, New Delhi.

Chikane, S. 2011. Notes on the habitat, natural history and distribution of the Three-lined Grass Skink, Eutropis trivittata (Hardwicke \& Gray, 1827) (Sauria: Scincidae) in Kaas, Northern Western Ghats, India. Sauria 33(4): 75-78.

Chopra, R.N. 1964. Notes on some lizards of Poona. Journal of the University of Poona, Science \& Technology 28: 39-42.

Daniels, J.C. 2002. The Book of Indian Reptiles and Amphibians. Oxford University Press, New York.

Gajbhiye K.S. and C. Mandal. 2000. Agro-ecological zones, their soil resource and cropping systems, pp. 1-32. In: Cropping Systems: Status of Farm Mechanization in India. Indian Agricultural Statistics Research Institute, New Delhi.

Hardwicke, T. and J.E. Gray. 1827. A synopsis of the species of saurian reptiles, collected in India by Major-General Hardwicke. Zoology Journal, London 3: 214-229.

Seetharamaraju, M., C. Srinivasulu, B. Srinivasulu, and R. Sreekar. 2011. Squamata, Scincidae, Eutropis trivittata (Hardwicke and Gray, 1827): Distribution extension. Check List 7: 363-364.

Smith, M.A. 1935. The Fauna of British India, Ceylon and Burma, Including the Whole of the Indo-Chinese Sub-region. Reptilia and Amphibia. Vol. II. Sauria. Taylor and Francis, London, UK.

Tikadar, B.K. and R.C. Sharma. 1992. Handbook of Indian Lizards. Zoological Survey of India, Kolkata.

Venugopal, P.D. 2010. An updated and annotated list of Indian lizards (Reptilia: Sauria) based on a review of distribution records and checklists of Indian reptiles. Journal of Threatened Taxa 2: 725-738. 